\title{
Rевенст АвтіскE: Evaluation and adoption of IPM modules in rice in Krishna district of Andhra Pradesh
}

P. Srilatha and Ch. Srilatha Vani

Article Chronicle:

Received :

18.03.2020;

Revised:

05.06.2020;

Accepted :

25.07.2020

Key Words : Integrated pest management (IPM), Frontline demonstrations, Cultural practice, Biological practice, Mechanical practice

Author for correspondence :

\section{P. Srilatha}

Krishi Vigyan Kendra, Ghantasala, Krishna

(A.P.) India

Email: srilathajeyabal@ gmail. com

See end of the article for authors' affiliations
SUMMARY : India is the second largest producer and consumer of rice grown in the world after China. Pest and disease intensity is increasing slowly due to many factors. The control of leaf folder and stem borer, many methods has been adopted but insecticides are still playing a key role for its control. Integrated Pest Management (IPM) is one of the ecofriendly approach which can be utilized to control the non-judicial uses of insecticides to control rice insect pest. Krishi Vigyan Kendra, Ghantasala conducted frontline demonstrations to demonstrate the efficacy of rice IPM technology on farmers' field under real farming situation during Kharif 2014 to 2016 . Altogether totally 45 demonstrations were laid out over an area of 12 hectares. Increased yield ranged from 28.50 to $35.25 \mathrm{q} / \mathrm{ha}$ with average yield of $31.90 \mathrm{q} / \mathrm{ha}$ was observed in IPM module and also recorded highest grain yield of rice $35.25 \mathrm{q} / \mathrm{ha}$ in IPM module compared to non- IPM module. It has been observed that among IPM trained farmers, various cultural practices have wide spread adoption as against very low adoption of biological practices. Because of poor knowledge about pest-specific lures, its use and non - availability lead to poor adoption of the mechanical practices. The major problems reported in biological practices and its adoption were its slow action against the target pest, lack of easy availability, short shelf-life and low survival of these bio-agents on farmers' field. Therefore, more awareness programmes and more demonstrations should be demonstrated on IPM module which is eco-friendly and safer to non-targeted organism in comparison to conventional insecticides.

How to cite this article : Srilatha, P. and Srilatha Vani, Ch. (2020). Evaluation and adoption of IPM modules in rice in Krishna district of Andhra Pradesh. Agric. Update, 15(4): 274-276; DOI : 10.15740/HAS/AU/15.4/274276. Copyright@2020: Hind Agri-Horticultural Society. 